\title{
Felodipine inhibits ox-LDL-induced reactive oxygen species production and inflammation in human umbilical vein endothelial cells
}

\author{
JIE QI $^{1 *}$, JIAN-BAO ZHENG $^{2 *}$, WEN-TING AI ${ }^{1}$, XIAO-WEI YAO ${ }^{1}$, LEI LIANG $^{1}$, \\ GONG CHENG $^{1}$, XI-LING SHOU ${ }^{1}$ and CHAO-FENG SUN ${ }^{3}$
}

${ }^{1}$ Second Department of Cardiovascular Medicine, Shaanxi Provincial People's Hospital, Xi'an, Shaanxi 710068;

Departments of ${ }^{2}$ General Surgery and ${ }^{3}$ Cardiovascular Medicine, First Affiliated Hospital

of Xi'an Jiaotong University, Xi'an, Shaanxi 710061, P.R. China

Received August 20,2016; Accepted May 25, 2017

DOI: $10.3892 / \mathrm{mmr} .2017 .7181$

\begin{abstract}
Oxidative stress and inflammation are involved in the pathogenesis of atherosclerosis. Calcium channel blockers (CCBs) inhibit the development of atherosclerosis, although the underlying molecular basis has not been completely elucidated. The present study was designed to investigate the effects of felodipine, a CCB, on inflammation and oxidative stress in human umbilical vein endothelial cells (HUVECs) and to examine the underlying mechanisms of action. Oxidized low-density lipoprotein (ox-LDL) was used to induce an inflammatory response in HUVECs. The effects of felodipine were investigated by measuring the content of nitric oxide (NO) and reactive oxygen species (ROS), the mRNA and protein levels of intercellular adhesion molecule 1 (ICAM-1) and vascular cell adhesion protein 1 (VCAM-1), and the mRNA levels of endothelial NO synthase (eNOS) and inducible NO synthase (iNOS), in addition to the adhesion ability of U937 cells to HUVECs. ROS and NO levels were significantly increased in HUVECs following 24-h treatment with $25 \mathrm{mg} / 1$ ox-LDL $(\mathrm{P}<0.01)$. The increase in ROS was reversed by treatment with felodipine. In addition, NO levels were increased following treatment with $1 \mu \mathrm{mol} / \mathrm{l}$ felodipine
\end{abstract}

Correspondence to: Dr Chao-Feng Sun, Department of Cardiovascular Medicine, First Affiliated Hospital of Xi'an Jiaotong University, 277 West Yanta Road, Xi'an, Shaanxi 710061, P.R. China E-mail: suncfsky@163.com

"Contributed equally

Abbreviations: HUVECs, human umbilical vein endothelial cells; ox-LDL, oxidized low-density lipoprotein; ROS, reactive oxygen species; NO, nitric oxide; ICAM-1, intercellular adhesion molecule 1; VCAM-1, vascular cell adhesion protein 1; eNOS, endothelial nitric oxide synthase; iNOS, inducible nitric oxide synthase; $\mathrm{CCB}$, calcium channel blocker

Key words: atherosclerosis, oxidative stress, inflammation, felodipine
$(\mathrm{P}<0.05)$. The mRNA expression of ICAM-1, VCAM-1, eNOS and iNOS was increased $(\mathrm{P}<0.05)$. Administration of $0.1 \mu \mathrm{M}$ felodipine significantly decreased the expression of ICAM-1, VCAM-1, and iNOS ( $\mathrm{P}<0.05)$. The number of U937 cells adhered to ox-LDL-treated HUVECs was significantly increased compared with control, which was reversed by felodipine $(0.1 \mu \mathrm{M})$. In conclusion, felodipine was demonstrated to inhibit oxidative stress and inflammatory responses, suggesting that it may be used to treat atherosclerosis.

\section{Introduction}

Accumulating evidence suggests an important role for oxidative stress and inflammation in the development of atherosclerosis $(1,2)$, in which intracellular $\mathrm{Ca}^{2+}$ contributes to the activation of a variety of signal transduction pathways (3). $\mathrm{Ca}^{2+}$ has been observed to be important in the signal transduction pathways implicated in the modified low-density lipoprotein (LDL)-triggered generation of tumor necrosis factor (TNF)- $\alpha(4,5)$. Therefore, $\mathrm{Ca}^{2+}$ regulates oxidative stress and inflammation in the development of atherosclerosis.

Oxidized LDL (ox-LDL) is able to trigger and sustain atherosclerotic lesions by increasing the synthesis of reactive oxygen species (ROS), which promotes atherogenesis and increases the transcription of intercellular adhesion molecule 1 (ICAM-1) and vascular cell adhesion protein 1 (VCAM-1) (6,7). Nitric oxide (NO), a free radical with the capacity to remove other free radicals, protects cells against pathological insults (8), and interference with NO bioavailability may diminish cardioprotection and exacerbate disease progression (9). Members of the nitric oxide synthase (NOS) family are involved in the generation of $\mathrm{NO}$, including endothelial NOS (eNOS), inducible NOS (iNOS) and neuronal NOS (nNOS), all of which require $\mathrm{Ca}^{2+} /$ calmodulin, flavin adenine dinucleotide (FAD), flavin mononucleotide and tetrahydrobiopterin as co-factors $(10,11)$. The production of iNOS is regulated by a number of mediators, including inflammatory cytokines and NO concentration. In vessels, NO is synthesized from the endothelium by eNOS. iNOS is associated with the processes of acute and chronic inflammatory responses (12). 
Calcium channel blockers (CCBs) are extensively administered for the treatment of a variety of cardiovascular diseases, including arrhythmias, angina pectoris and hypertension (13). Amlodipine, a CCB, decreases the incidence of cardiac adverse events in addition to inhibiting the progression of carotid artery atherosclerosis (14). A number of CCBs decrease atherosclerotic lesions, oxidative stress and the levels of inflammatory cytokines, without markedly influencing the levels of blood lipids and glucose metabolism $(15,16)$. The anti-atherosclerotic activity of CCBs is not always accompanied by decreased blood pressure, suggesting that CCBs may protect blood vessels independently of their blood pressure decreasing effects. However, the underlying mechanisms behind these processes remain unclear.

Felodipine, a dihydropyridine $\mathrm{CCB}$, is used to treat angina pectoris and hypertension (17). In apolipoprotein $\mathrm{E}$ (ApoE)-deficient mice, felodipine has been demonstrated to effectively inhibit atherogenesis (18). Felodipine decreases vascular inflammation through repression of the activation of nuclear factor (NF)- $\mathrm{\kappa B}(19)$. However, the direct interactions between free radicals and CCBs have not been completely elucidated.

Human umbilical vein endothelial cells (HUVECs) are frequently used as a cellular model to probe the mechanisms underlying the pathogenesis of cardiovascular diseases. The present study aimed to examine the hypothesis that felodipine may prevent ox-LDL-induced endothelial dysfunction via downregulation of ROS and NO generation. The present study investigated whether felodipine exhibited the ability to scavenge free radicals and prevent oxidative damage. The effects of felodipine on ox-LDL-induced NO generation and on other downstream events were assessed, including the expression levels of eNOS and iNOS, adhesion molecules, and the adherence of monocytic U937 cells to HUVECs.

\section{Materials and methods}

Reagents. Antibodies against ICAM-1 (cat. no. sc-71292), VCAM-1 (cat. no. sc-18854), factor VIII (cat. no. sc-14014), and $\beta$-actin (cat. no. sc-47778) were obtained from Santa Cruz Biotechnology, Inc. (Dallas, TX, USA). The ABC Elite kit (used for immunofluorescence staining) and the secondary antibodies [cat. no. BA-1105 (immunofluorescence staining); cat. no. BA-1051 (western blotting)] were purchased from Wuhan Boster Biological Technology, Ltd. (Wuhan, China). All other reagents were purchased from either Shaanxi Pioneer Biotech Co., Ltd. (Xi'an, China) or Sigma-Aldrich (Merck KGaA, Darmstadt, Germany), unless otherwise stated.

Cells and cell culture. Initially, HUVECs were individually derived from the endothelium of postpartum umbilical cord veins in 5 postpartum women (age, 24-35 years) who had delivered in the First Affiliated Hospital, Xi'an Jiaotong University (Xi'an, China) between June 2009 and October 2009. Following observations, the HUVECs selected for the present study were derived from only one of these postpartum women (age, 26 years) as they exhibited the greatest cellular growth behavior. Patients provided written informed consent, and the Ethics Committee of the First Affiliated Hospital, Xi'an Jiaotong University (Xi'an, China) approved the experimental protocol. HUVECs were enzymatically isolated and cultured as reported previously (20). Following enzymatic digestion, the cells were maintained in Medium 199 (Sigma-Aldrich; Merck $\mathrm{KGaA}$ ) containing low serum growth supplements, $100 \mathrm{IU} / \mathrm{ml}$ penicillin, and $0.1 \mathrm{mg} / \mathrm{ml}$ streptomycin (all from Gibco; Thermo Fisher Scientific, Inc., Waltham, MA, USA). The culture medium was replenished every 2 days. The monocytotic U937 cells (American Type Culture Collection, Manassas, VA, USA) were cultured in RPMI-1640 medium (Sigma-Aldrich; Merck KGaA) supplemented with $10 \%$ fetal calf serum (Sigma-Aldrich; Merck KGaA).

Immunofluorescence staining was performed to visualize the expression of factor VIII, an endothelial cell marker. The cells $\left(1 \times 10^{5}\right.$ cells $\left./ \mathrm{ml}\right)$ were cultured on glass cover slips and were fixed with 4\% paraformaldehyde (Shaanxi Pioneer Biotech Co., Ltd.) for $15 \mathrm{~min}$ at room temperature, followed by permeabilization with $0.1 \%$ Triton X-100 (Shaanxi Pioneer Biotech Co., Ltd.). The cells were blocked in $4 \%$ goat serum (Sigma-Aldrich; Merck KGaA) for $1 \mathrm{~h}$ at room temperature, probed with rabbit anti-factor VIII-related antibody $(1: 1,000)$ at $4^{\circ} \mathrm{C}$ overnight, washed twice with PBS, and subsequently incubated with the secondary antibody (fluorescein isothiocyanate-conjugated goat anti-rabbit immunoglobulin $\mathrm{G} ; 1: 100)$ at $37^{\circ} \mathrm{C}$ for $1 \mathrm{~h}$. The cover slips were mounted on microscope slides, and fluorescence was visualized under a microscope (Leica DMi8; Leica Microsystems GmbH, Wetzlar, Germany).

Lipoprotein and preparation of ox- $L D L$. Native LDL was purified and oxidized in fresh normolipidemic human serum by sequential ultra-centrifugation, as described previously (21). The kinetics of LDL oxidation of the EDTA-free LDL were measured by the absorbance $(232 \mathrm{~nm})$ of conjugated diene at $37^{\circ} \mathrm{C}$ for up to $6 \mathrm{~h}$. When required, LDL oxidation was assessed by determination of the production of thiobarbituric acid-reactive substances (22). The end product of lipid peroxidation, malondialdehyde, was taken as a standard.

Treatment of HUVECs. HUVECs were pre-treated with ox-LDL at various concentrations $(6,12.5$ and $25 \mathrm{mg} / \mathrm{l})$ for $24 \mathrm{~h}$ at room temperature and subsequently incubated with ox-LDL $(25 \mathrm{mg} / \mathrm{l})$ for $24 \mathrm{~h}$ with felodipine at different concentrations $(0.1,1$ and $10 \mu \mathrm{mol} / \mathrm{l})$ or control (cells incubated in culture medium only) at room temperature. The potential protective effects of felodipine against oxidative stress and inflammation were assessed by measuring the levels of intracellular ROS production, the mRNA expression of target genes in ox-LDL-treated HUVECs, and the adhesion ability of monocytic U937 cells to HUVECs.

Determination of intracellular ROS. ROS production was evaluated with a fluorometric assay, using 2',7'-dichlorofluorescein 3',6'-diacetate (DCFH-DA; Sigma-Aldrich; Merck KGaA). Following treatment with ox-LDL and felodipine, the HUVECs $\left(1 \times 10^{5}\right.$ cells $\left./ \mathrm{ml}\right)$ were incubated with DCFH-DA $(20 \mu \mathrm{mol} / \mathrm{l})$ for $30 \mathrm{~min}$ at room temperature. The fluorescence intensity of DCFH-DA-labeled cells was determined using a FACScan flow cytometer (BD Biosciences, San Jose, CA, USA) and the data were analyzed using Cell-Quest software v3.0 (BD Biosciences). 
Reverse transcription-quantitative polymerase chain reaction $(R T-q P C R)$ analysis. TRIzol reagent (Invitrogen; Thermo Fisher Scientific, Inc.) was used to extract total RNA from HUVECs, according to the manufacturer's protocol (23). RNA concentration was determined using a NanoDrop spectrophotometer (NanoDrop Technologies; Thermo Fisher Scientific, Inc., Wilmington, DE, USA) by measuring the A260/A280 ratio. The PrimeScript ${ }^{\mathrm{TM}}$ 1st Strand cDNA Synthesis kit (Takara Bio, Inc., Otsu, Japan) was used to convert the RNA into cDNA. First-strand cDNA synthesis was performed in a $10 \mu \mathrm{l}$ total reaction volume containing $2.5 \mu \mathrm{g}$ of total RNA, $1 \mu \mathrm{l}$ Oligo dT Primer $(50 \mu \mathrm{M}), 1 \mu \mathrm{ldNTP}$ Mixture $(10 \mathrm{mM}$ each) and RNase-free $\mathrm{dH}_{2} \mathrm{O}$ up to $10 \mu \mathrm{l}$. The $10 \mu \mathrm{l}$ of RT reaction mixture was heated to $65^{\circ} \mathrm{C}$ for $5 \mathrm{~min}$ and annealed primer template samples were then snapped on ice. Then, $4 \mu 1$ of $5 \mathrm{X}$ PrimeScript buffer, $0.5 \mu 1$ RNase Inhibitor and $1 \mu \mathrm{l}$ PrimeScript RTase (all supplied in the kit) were added to the $10 \mu \mathrm{l}$ of RT reaction mixture. Reverse transcription was carried out at $42^{\circ} \mathrm{C}$ for $1 \mathrm{~h}$ and $95^{\circ} \mathrm{C}$ for $5 \mathrm{~min}$. The forward and reverse primers (Sangon Biotech Co., Ltd., Shanghai, China) used for RT-qPCR analysis were as follows: Human GAPDH sense, 5'-CTCTCTGCTCCTCCTGTTCGACAG-3' and antisense, 5'-GTGGAATCATATTGGAACATGTAG-3'; ICAM-1 sense, 5'-CCGGAAGGTGTATGAACGT-3' and antisense, 5'-TCCATGGTGATCTCTCCTC-3'; VCAM-1 sense, 5'-GGG ACCACATCTACGCTGACAA-3' and antisense, 5'-GGCCAC TCAAATGAATCTCTGGA-3'; eNOS sense, 5'-GACGCT ACGAGGAGTGGAAGTGGTTC-3' and antisense, 5'-CAG GGCAAGCTGGGATCGGG-3'; and iNOS sense, 5'-AGC AGCATCCACGCCAAGAA-3' and antisense, 5'-GAACAA TCCACAACTCGCTCC-3'. qPCR analysis was performed in 96-well plates, with an iCycler ${ }^{\mathrm{TM}}$ iQ System (Bio-Rad Laboratories, Inc., Hercules, CA, USA). The reaction mixture (final volume, $20 \mu \mathrm{l}$ ) contained $6 \mu \mathrm{l}$ cDNA, $20 \mathrm{nM}$ forward primer, $20 \mathrm{nM}$ reverse primer and $10 \mu \mathrm{l} \mathrm{SYBR-Green} \mathrm{II} \mathrm{PCR}$ Master mix (Applied Biosystems; Thermo Fisher Scientific, Inc.). The reaction conditions for the PCR were as follows: $50^{\circ} \mathrm{C}$ for $2 \mathrm{~min}, 95^{\circ} \mathrm{C}$ for $10 \mathrm{~min}$, and 40 cycles of $95^{\circ} \mathrm{C}$ for $5 \mathrm{~min}, 58.5^{\circ} \mathrm{C}$ for $15 \mathrm{~min}$ and $72^{\circ} \mathrm{C}$ for $10 \mathrm{~min}$. The relative level of amplified RNA was calculated using the $2^{-\Delta \Delta \mathrm{Cq}}$ method (24).

Western blotting. HUVECs were treated with ox-LDL $(25 \mathrm{mg} / \mathrm{l})$ for $24 \mathrm{~h}$ and felodipine at different concentrations $(0.1,1$, and $10 \mu \mathrm{mol} / 1)$. Whole cell lysates were made and nuclear extracts were purified with a protein extraction kit (Applygen Technologies Inc., Beijing, China), and a bicinchoninic acid protein assay reagent kit (Novagen; Merck KGaA) was used to determine the protein concentration. Protein lysates (40 $\mu \mathrm{g} /$ lane) were separated using SDS-PAGE on a $10 \%$ gel (Sigma-Aldrich; Merck KGaA) and the samples were transferred onto an Immobilon-P membrane (EMD Millipore, Billerica, MA, USA). The membrane was blocked in $1 \mathrm{X}$ PBS containing $5 \%(\mathrm{w} / \mathrm{v})$ non-fat milk and $0.05 \%(\mathrm{v} / \mathrm{v})$ Tween-20 (Sigma-Aldrich; Merck KGaA) for $1 \mathrm{~h}$ at room temperature, and subsequently incubated with the primary antibodies against ICAM-1 (1:500) or VCAM-1 (1:500) at $4^{\circ} \mathrm{C}$ overnight. Following washing, the membrane was probed with horseradish peroxidase-conjugated secondary antibody $(1: 5,000)$ for $1 \mathrm{~h}$ at room temperature. Immunoreactive bands were detected using an enhanced chemiluminescence kit (GE
Healthcare Life Sciences, Little Chalfont, UK). Band intensities were quantified by densitometry using TotalLab TL100 v2006 software (Nonlinear Dynamics, Ltd., Newcastle upon Tyne, UK). $\beta$-actin $(1: 1,000)$ was used as an internal loading control.

Measurement of NO production. The NO level was quantified by measuring nitrite and nitrate. Nitrate reductase triggers the conversion of nitrate to nitrite and the overall generation of nitrite was examined using the Griess reaction, as reported previously (25). HUVECs in the different intervention groups were incubated with a solution containing nitrate reductase $(0.2 \mathrm{U} / \mathrm{ml})$, FAD $(5 \mathrm{mM})$, and reduced nicotinamide adenine dinucleotide phosphate $(50 \mathrm{mM})$ at $37^{\circ} \mathrm{C}$ for $20 \mathrm{~min}$. The reaction was terminated by the addition of sodium pyruvate $(10 \mathrm{mM})$ and lactate dehydrogenase $(24 \mathrm{mg} / \mathrm{ml})$, and the products were precipitated with $1.4 \% \mathrm{ZnSO}_{4}$. The total nitrite was reacted with Griess reagent, containing $1 \%$ sulphanilamide, $2.5 \% \mathrm{PO}_{4} \mathrm{H}_{3}$ and $0.1 \% \mathrm{n}$-naphthyl-ethylene-diamine, and was evaluated by the absorbance at $550 \mathrm{~nm}$ using a universal microplate spectrophotometer (Bio-Rad Laboratories, Inc.).

In vitro monocyte adhesion assay. The HUVECs $\left(5 \times 10^{4}\right.$ cells/well) were cultured in 24 -well plates. For the pharmacological experiments, the cells were treated with $25 \mathrm{mg} / \mathrm{l}$ ox-LDL in the presence or absence of $0.1 \mu \mathrm{M}$ felodipine. At $24 \mathrm{~h}$ post-drug incubation, $4 \times 10^{6} \mathrm{U} 937$ cells in $500 \mu \mathrm{l}$ medium were added to each well with the confluent monolayers of HUVECs and the cell cultures were incubated for a further $30 \mathrm{~min}$. Gentle aspiration was performed to eliminate non-adherent monocytes. The average number of adherent cells was scored in 3 separate fields per well under an optical microscope (original magnification, x200; Leica DMi8; Leica Microsystems GmbH, Wetzlar, Germany). Each treatment was repeated in quadruplicate.

Statistical analysis. The data are expressed as the mean \pm standard error of the mean and were analyzed using one-way analysis of variance followed by Bonferroni's post hoc test. $\mathrm{P}<0.05$ was considered to indicate a statistically significant difference. All statistical analyses were performed using SPSS software, version 13.0 (SPSS, Inc., Chicago, IL, USA).

\section{Results}

Morphology. The HUVECs grew as confluent monolayers with a cobblestone-like morphology (Fig. 1A). Expression of factor VIII, a marker of endothelial cells, was confirmed by immunofluorescence staining (Fig. 1B).

Felodipine decreases ROS generation triggered by ox-LDL in HUVECs. Ox-LDL evoked a gradual increase in intracellular ROS, leading to apoptosis in HUVECs. ROS were increased in HUVECs following treatment with a variety of concentrations of ox-LDL $(6,12.5$ and $25 \mathrm{mg} / \mathrm{l})$ for $24 \mathrm{~h}$, and there was a highly significant difference with $25 \mathrm{mg} / \mathrm{l}$ ox-LDL $(\mathrm{P}<0.01$; Fig. 2A). A dosage of $25 \mathrm{mg} / \mathrm{ml}$ ox-LDL was used to investigate the protective effect of felodipine against ox-LDL-induced HUVEC injury in the following experiments. Treatment with felodipine at various concentrations $(0.1,1$ and $10 \mu \mathrm{mol} / \mathrm{l})$ for 
Table I. Effects ox-LDL on the mRNA levels of ICAM-1, VCAM-1, eNOS and iNOS.

\begin{tabular}{lccccc}
\hline & Control & DMSO & $6 \mathrm{mg} / \mathrm{lox}-\mathrm{LDL}$ & $12.5 \mathrm{mg} / \mathrm{l} \mathrm{ox}-\mathrm{LDL}$ & $25 \mathrm{mg} / \mathrm{l} \mathrm{ox}-\mathrm{LDL}$ \\
\hline ICAM-1 & 1.00 & $0.96 \pm 0.05$ & $1.18 \pm 0.24$ & $1.74 \pm 0.34$ & $2.24 \pm 0.25^{\mathrm{a}}$ \\
VCAM-1 & 1.00 & $0.99 \pm 0.03$ & $1.17 \pm 0.33$ & $1.51 \pm 0.47$ & $2.69 \pm 0.38^{\mathrm{a}}$ \\
eNOS & 1.00 & $1.00 \pm 0.08$ & $1.28 \pm 0.25$ & $1.66 \pm 0.32$ & $2.92 \pm 0.74^{\mathrm{a}}$ \\
iNOS & 1.00 & $0.98 \pm 0.13$ & $2.04 \pm 0.24$ & $5.32 \pm 0.54^{\mathrm{a}}$ & $14.95 \pm 1.14^{\mathrm{a}}$ \\
\hline
\end{tabular}

Data are expressed as $2^{-\Delta \Delta \mathrm{Cq}}$ (mean). ${ }^{\text {a }}<<0.05$ vs. control. ox-LDL, oxidized low-density lipoprotein; ICAM-1, intercellular adhesion molecule 1; VCAM-1, vascular cell adhesion protein 1; eNOS, endothelial nitric oxide synthase; iNOS, inducible nitric oxide synthase; DMSO, dimethyl sulfoxide.
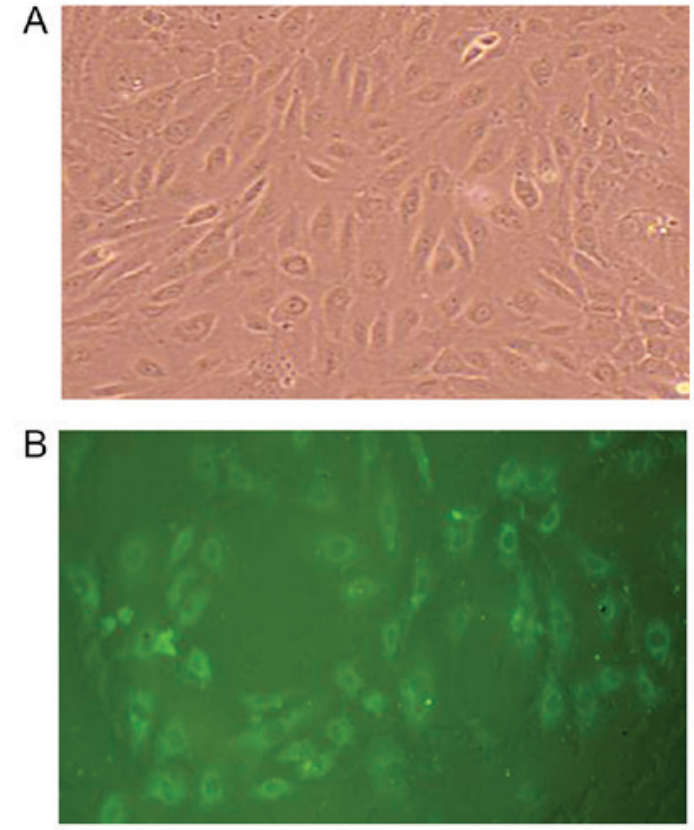

Figure 1. Characterization of primary cultured HUVECs. (A) Cobblestoneshaped HUVECs were visualized under a microscope after 5 days of in vitro culture (original magnification, x200). (B) The marker of endothelial cells, factor VIII, was observed to be expressed using immunofluorescence staining (original magnification, x200). HUVECs, human umbilical vein endothelial cells.

$24 \mathrm{~h}$ significantly decreased the ROS generation induced by ox-LDL ( $\mathrm{P}<0.05$; Fig. 2B).

Felodipine decreases the mRNA levels of ICAM-1, VCAM-1, eNOS and $i N O S$ in ox-LDL-treated HUVECs. The ox-LDL $(25 \mathrm{mg} / \mathrm{l})$ treatment resulted in a significant increase in the mRNA levels of ICAM-1, VCAM-1, eNOS and iNOS compared with controls $(\mathrm{P}<0.05$; Table I). However, co-treatment with felodipine $(0.1 \mu \mathrm{mol} / \mathrm{l})$ reversed the increases in the mRNA levels of ICAM-1, VCAM-1 and iNOS (P<0.05; Table II), although the same result was not observed with eNOS.

Felodipine suppresses monocyte adhesion to HUVECs treated with ox- $L D L$. Treatment with ox-LDL induced endothelial cell damage by increasing the production of adhesion molecules, resulting in the tethering, activation and attachment of monocytes to the endothelial cells. In order to examine the effects of felodipine on the ox-LDL-stimulated adhesion of monocytes
A

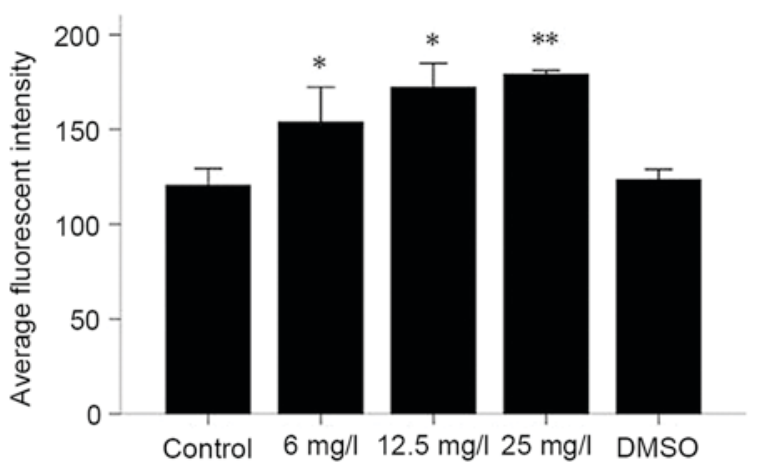

B

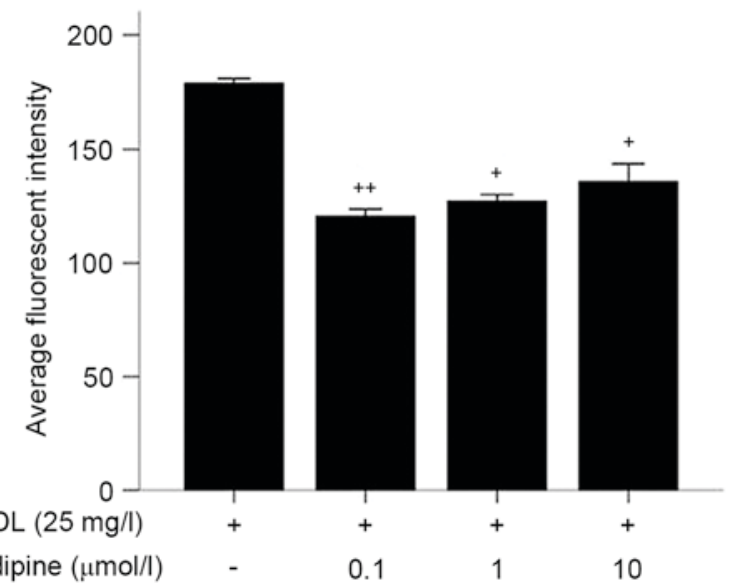

Figure 2. Effect of felodipine on ROS production in ox-LDL-treated HUVECs. (A) ROS levels in the supernatants of HUVEC cultures incubated with ox-LDL. (B) Cells were incubated with ox-LDL ( $25 \mathrm{mg} / \mathrm{l})$ and felodipine $(0,0.1,1$ or $10 \mu \mathrm{M})$ for $24 \mathrm{~h}$. The ROS levels in the supernatants of cell cultures were determined by 2', 7'-dichlorofluorescein 3', 6'-diacetate staining followed by fluorescence activated cell sorting analysis. ${ }^{*} \mathrm{P}<0.05,{ }^{* * *} \mathrm{P}<0.01$ vs. control; ${ }^{+} \mathrm{P}<0.05,{ }^{++} \mathrm{P}<0.01$ vs. ox-LDL only. ROS, reactive oxygen species; ox-LDL, oxidized low-density lipoprotein; HUVECs, human umbilical vein endothelial cells; DMSO, dimethyl sulfoxide.

to HUVECs, confluent monolayers of HUVECs were treated with ox-LDL $(25 \mathrm{mg} / \mathrm{l})$ in the presence or absence of felodipine $(0.1 \mu \mathrm{M})$ for $24 \mathrm{~h}$, followed by incubation with $\mathrm{U} 937$ cells for $30 \mathrm{~min}$ at $37^{\circ} \mathrm{C}$. The ox-LDL treatment promoted the attachment of U937 cells to HUVECs, which was reversed by felodipine (Fig. 3).

Felodipine increases the release of NO into the medium in cultured HUVECs following ox-LDL treatment. In order to 
Table II. Effects of felodipine on the mRNA levels of ox-LDLinduced ICAM-1, VCAM-1, eNOS and iNOS.

\begin{tabular}{lcccc}
\hline & $\begin{array}{l}25 \mathrm{mg} / \mathrm{l} \\
\text { ox-LDL }\end{array}$ & $0.1 \mu \mathrm{M} \mathrm{Fel}$ & $1 \mu \mathrm{M} \mathrm{Fel}$ & $10 \mu \mathrm{M} \mathrm{Fel}$ \\
\hline ICAM-1 & 1.00 & $0.46 \pm 0.12^{\mathrm{a}}$ & $0.55 \pm 0.46$ & $0.80 \pm 0.15$ \\
VCAM-1 & 1.00 & $0.38 \pm 0.13^{\mathrm{a}}$ & $0.46 \pm 0.09$ & $0.71 \pm 0.14$ \\
eNOS & 1.00 & $1.47 \pm 0.61$ & $1.93 \pm 0.58$ & $1.24 \pm 0.19$ \\
iNOS & 1.00 & $0.28 \pm 0.14^{\mathrm{a}}$ & $0.59 \pm 0.21$ & $0.82 \pm 0.03$ \\
\hline
\end{tabular}

Data are expressed as $2^{-\Delta \Delta \mathrm{Cq}}$ (mean). ${ }^{\mathrm{a}} \mathrm{P}<0.05$ vs. $25 \mathrm{mg} / \mathrm{l}$ ox-LDL. ox-LDL, oxidized low-density lipoprotein; ICAM-1, intercellular adhesion molecule 1; VCAM-1, vascular cell adhesion protein 1; eNOS, endothelial nitric oxide synthase; iNOS, inducible nitric oxide synthase; Fel, felodipine.

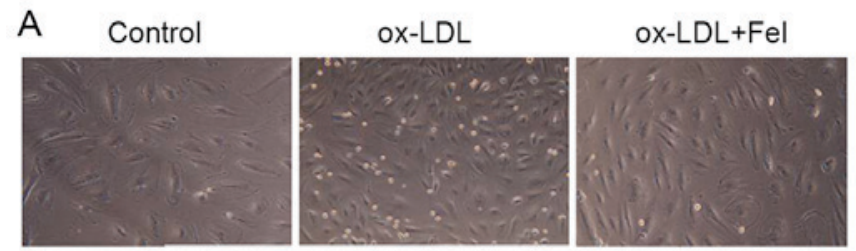

B

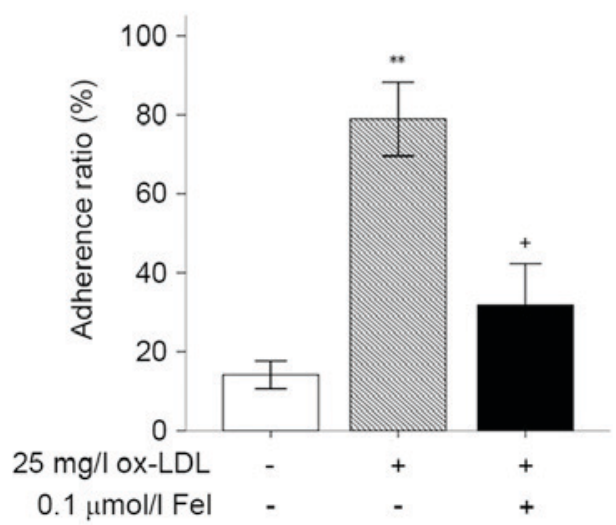

Figure 3. Effect of felodipine on adhesion of monocytes to HUVECs stimulated by ox-LDL. (A) HUVECs were treated with $25 \mathrm{mg} / \mathrm{lox}-\mathrm{LDL}$ in the presence or absence of $0.1 \mu \mathrm{M}$ felodipine for $24 \mathrm{~h}$, followed by co-incubation of U937 monocytes with HUVECs for $30 \mathrm{~min}$ at $37^{\circ} \mathrm{C}$ (original magnification, $\mathrm{x} 200$ ). (B) Adhesion assay analysis of the U937 monocyte adhesion to HUVECs. The data were calculated from three independent experiments. ${ }^{* *} \mathrm{P}<0.01$ vs. control; ${ }^{+} \mathrm{P}<0.05$ vs. ox-LDL only. HUVECs, human umbilical vein endothelial cells; ox-LDL, oxidized low-density lipoprotein; Fel, felodipine.

examine whether felodipine was able to facilitate the production and release of NO in HUVECs, the content of NO was assessed under various treatments. As presented in Fig. 4A, a dose-dependent increase in NO level was observed in the culture medium following treatment with ox-LDL for $24 \mathrm{~h}$. However, in the presence of felodipine for $24 \mathrm{~h}$, ox-LDL $(25 \mathrm{mg} / \mathrm{l})$ increased NO production only at a concentration of $1 \mu \mathrm{mol} / 1$ (Fig. 4B).

Felodipine suppresses the upregulation of ICAM-1 and VCAM-1 in ox-LDL-stimulated HUVECs. Ox-LDL has been demonstrated to upregulate the levels of adhesion molecules,
A

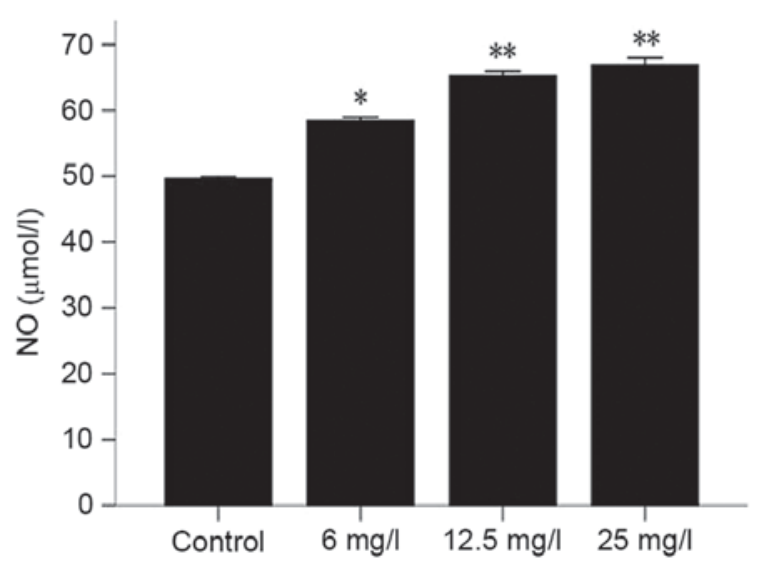

B

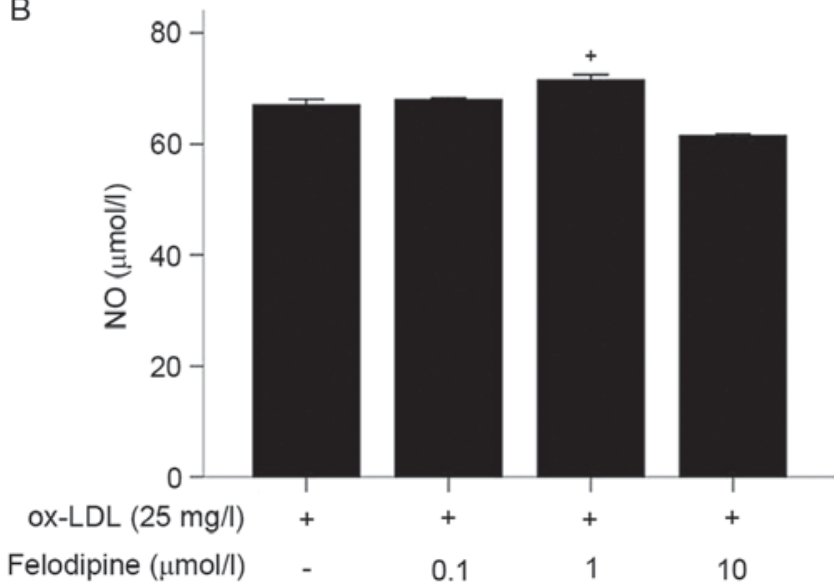

Figure 4. Effect of felodipine on the ox-LDL-induced NO concentration in the culture medium. (A) Human umbilical vein endothelial cells were pretreated with ox-LDL $(6,12.5$ and $25 \mathrm{mg} / \mathrm{l})$ for $24 \mathrm{~h}$, and subsequently co-incubated with ox-LDL ( $25 \mathrm{mg} / \mathrm{l})$ and felodipine for $24 \mathrm{~h}$ (B) The culture medium was collected for measuring the NO concentration. Each treatment was repeated in triplicate. ${ }^{*} \mathrm{P}<0.05,{ }^{* *} \mathrm{P}<0.01$ vs. control; ${ }^{+} \mathrm{P}<0.05$ vs. $25 \mathrm{mg} / 1$ ox-LDL alone. NO, nitric oxide; ox-LDL, oxidized low-density lipoprotein.

including ICAM-1 and VCAM-1, in HUVECs (26). The present study aimed to identify the concentration of ox-LDL that was able to cause HUVEC injury and upregulate the protein expression levels of adhesion molecules. In order to maintain consistency with the mRNA findings in the present study, $25 \mathrm{mg} / \mathrm{l}$ ox-LDL was used in subsequent experiments. Treatment with $25 \mathrm{mg} / \mathrm{l}$ ox-LDL increased the expression of ICAM-1 and VCAM-1 (Fig. 5A). It was further investigated whether felodipine was able to decrease the expression of ICAM-1 and VCAM-1, upregulated by ox-LDL, in HUVECs. Treatment with $25 \mathrm{mg} / \mathrm{l}$ ox-LDL increased the levels of ICAM- 1 and VCAM- 1 at $24 \mathrm{~h}$, while felodipine $(0.1 \mu \mathrm{mol} / \mathrm{l})$ decreased the ox-LDL-increased ICAM-1 and VCAM-1 levels $(\mathrm{P}<0.05$; Fig. 5B).

\section{Discussion}

Oxidative stress frequently results in alterations in a variety of functional responses in endothelial cells, which is considered to be important for the development of cardiovascular disease (27). Endothelial dysfunction influences the development and stability of plaques, one of the most important pathological changes in atherosclerosis (28). Accumulating 


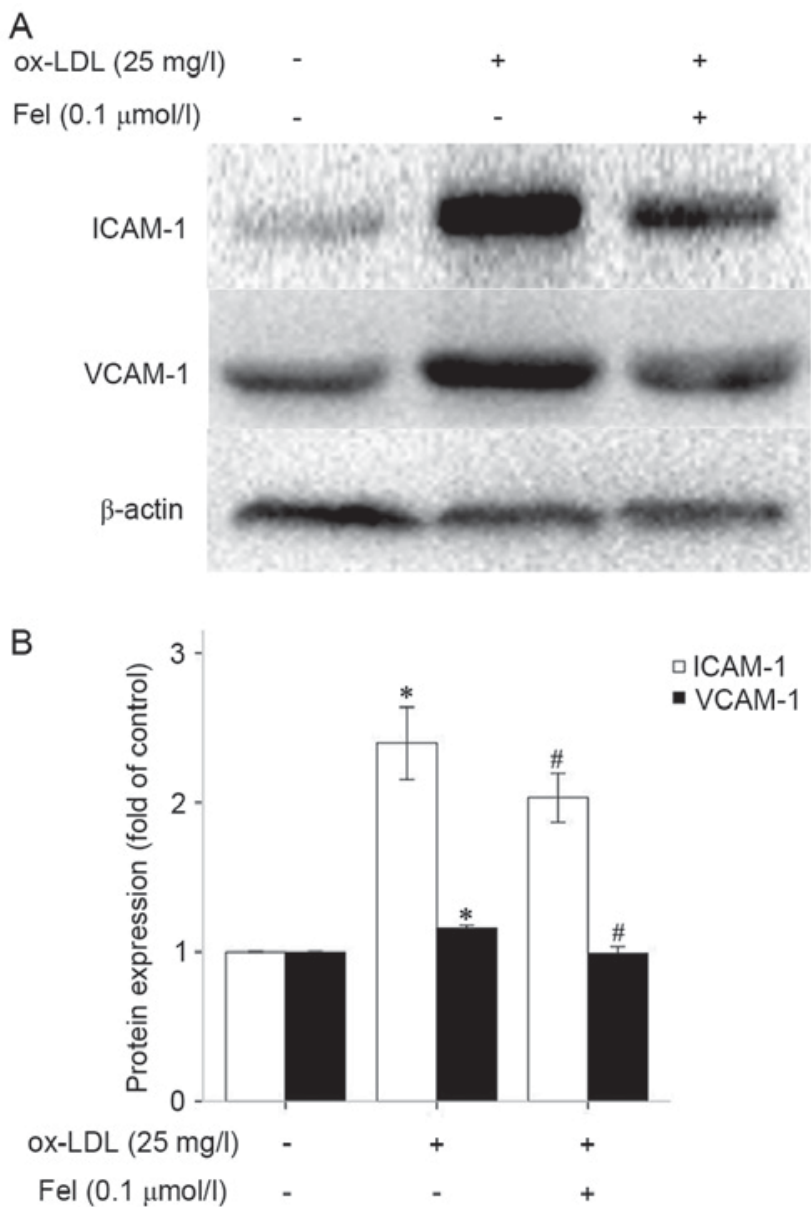

Figure 5. Effect of felodipine on the expression of ICAM-1 and VCAM-1 in HUVECs stimulated by ox-LDL. (A) Western blotting of ICAM-1 and VCAM-1 expression in HUVECs was performed. (B) Quantification of average expression of ICAM-1 and VCAM-1 expression in HUVECs. Data were derived from three independent experiments and are presented as a fold change vs. the control. ${ }^{*} \mathrm{P}<0.05$ vs. control; ${ }^{~} \mathrm{P}<0.05$ vs. ox-LDL alone. ICAM-1, intercellular adhesion molecule 1; VCAM-1, vascular cells adhesion molecule 1; HUVECs, human umbilical vein endothelial cells; ox-LDL, oxidized low-density lipoprotein; Fel, felodipine.

evidence obtained from clinical and scientific studies has demonstrated that CCBs are able to efficiently prevent atherogenesis (29-31). The present study investigated the hypothesis that the calcium antagonist felodipine may prevent lipid peroxidation, including LDL oxidation.

The oxidative stress triggered by ox-LDL promotes apoptotic signaling pathways, resulting in endothelial cell death. An increase in ROS synthesis is the earliest apoptosis-associated event induced by ox-LDL, and a number of subsequent downstream events are activated by secondary messengers (32). The results of the present study demonstrated that felodipine markedly diminished ox-LDL-induced ROS generation, indicating that felodipine suppressed the activation of oxidative stress signal transduction. Increased intracellular oxidative stress is associated with abnormalities in $\mathrm{Ca}^{2+}$ signaling and disturbances in normal cell function, leading to cell death and toxicity (33).

ROS-mediated perturbation of intracellular calcium homeostasis is an early event in cell injury (34). NO serves a role in numerous biological functions, including vasodilation, leukocyte adhesion, platelet aggregation and insulin sensitivity (35). Suppression of NO generation and bioavailability is implicated in the pathogenesis of atherosclerosis and metabolic syndrome (36). Studies on $\mathrm{ApoE}^{-/}$mice, which develop atherosclerotic lesions spontaneously following deletion of eNOS, have demonstrated the importance of NO in the development of atherogenesis (37). Compared with $\mathrm{ApoE}^{-1-}$ mice, ApoE-eNOS double-knockout mice exhibit increased formation of atherosclerotic plaques (38). Transgenic mice overexpressing eNOS have been observed to exhibit a decrease in plasma cholesterol levels and blood pressure, and a $40 \%$ decrease in the formation of atherosclerotic lesions when compared with $\mathrm{ApoE}^{-/}$mice (39). In addition, ApoE-iNOS double-knockout mice exhibit decreased formation of atherosclerotic plaques when compared with $\mathrm{ApoE}^{-/}$mice (40). These previous observations indicated that $\mathrm{NO}$ derived from eNOS may prevent atherosclerosis, while iNOS-generated NO may increase lesions.

Previous studies have demonstrated that CCBs promote NO synthesis and improve endothelial function (41-43). Certain dihydropyridine drugs may increase NO release from cultured cells or non-coronary arteries, possibly due to elevated eNOS activity or antioxidative effects $(44,45)$. However, no CCB-sensitive channel has been identified in endothelial cells and, therefore, the mechanism of action for CCBs remains elusive. A number of CCBs have been reported to increase eNOS protein expression (46), although amlodipine has been demonstrated to elevate NO production without altering the protein expression levels of eNOS (47). Yang et al (48) demonstrated that pranidipine augments $\mathrm{NO}$ action in the cultured endothelial cells through suppression of superoxide-triggered NO degradation, as supported by the finding that the drug upregulates superoxide dismutase. However, benidipine and nifedipine upregulate eNOS expression and NO production in cultured endothelial cells in murine models of obesity and type 2 diabetes $(43,49)$.

In the present study, it was demonstrated that felodipine did not notably increase eNOS mRNA expression levels dose-dependently, which may be associated with the ox-LDL concentration used, which was lower compared with other previous studies; therefore, intracellular $\mathrm{Ca}^{2+}$ was not able to stimulate the production of eNOS. A previous study reported that, in the process of ROS and NF- $\kappa \mathrm{B}$ activation, iNOS expression is elevated, which subsequently produces $\mathrm{NO}$ and causes tissue injury (50). NF- $\kappa \mathrm{B}$ is an important transcription factor that regulates the expression of inflammatory mediators, including iNOS, TNF- $\alpha$, and IL-1 $\beta$, which is considered to be the primary mechanism underlying ischemia-associated brain injury (51). Suppression of iNOS expression and NO production has been observed to protect from ischemia-associated injury in the brain (52). The data from the present study indicated that ox-LDL increased iNOS mRNA and that treatment with felodipine led to a decrease in iNOS mRNA and augmented NO release. It may be hypothesized that protective NO was primarily generated from eNOS, and not iNOS mechanisms. The results of the present study provided evidence that felodipine may exhibit beneficial effects by decreasing iNOS expression during the atherosclerotic process.

Inflammatory responses serve important roles in different stages of atherosclerosis, including initiation, thrombosis formation and the rupture of atherosclerotic plaques (53). Recruitment 
of inflammatory cells is involved at the early stage of atherosclerosis (54). Increased levels of ICAM-1 and VCAM-1 contribute to the initiation of early atherosclerosis, preferentially promoting monocyte adhesion (55). Therefore, inhibiting inflammation may prevent the further development of atherosclerosis at the early stages (56). The results of the present study demonstrated that ox-LDL treatment upregulated the expression of ICAM-1 and VCAM-1 in HUVECs, which was effectively reversed by felodipine. Additionally, ox-LDL treatment promoted monocytic adherence to HUVECs, which was inhibited by felodipine.

In conclusion, the results of the present study identified an anti-atherosclerotic mechanism by which felodipine may prevent the progression of atherosclerosis and inhibit clinical events associated with coronary artery disease. The present findings additionally indicated that treatment with felodipine decreased the levels of intracellular ROS, restored the activity of NO, and suppressed the expression of adhesion molecules and monocyte adhesion. In conclusion, felodipine exhibits a direct protective effect on vascular endothelial cells, which may support its application for the treatment of atherosclerosis.

\section{Acknowledgements}

The present study was supported by a grant from the National Natural Science Foundation of China (grant nos. 81101874 and 81172362), and the Science and Technology Project of Shaanxi Province (grant no. 2016SF-015).

\section{References}

1. Siti HN, Kamisah Y and Kamsiah J: The role of oxidative stress, antioxidants and vascular inflammation in cardiovascular disease (a review). Vascul Pharmacol 71: 40-56, 2015.

2. Husain K, Hernandez W, Ansari RA and Ferder L: Inflammation, oxidative stress and renin angiotensin system in atherosclerosis. World J Biol Chem 6: 209-217, 2015.

3. Kudryavtseva O, Aalkjaer C and Matchkov VV: Vascular smooth muscle cell phenotype is defined by $\mathrm{Ca} 2^{+}$-dependent transcription factors. FEBS J 280: 5488-5499, 2013.

4. Kao YH, Chen YC, Cheng CC, Lee TI, Chen YJ and Chen SA: Tumor necrosis factor-alpha decreases sarcoplasmic reticulum $\mathrm{Ca} 2^{+}$-ATPase expressions via the promoter methylation in cardiomyocytes. Crit Care Med 38: 217-222, 2010.

5. Pollaud-Chérion C, Vandaele J, Quartulli F, Séguélas MH, Decerprit J and Pipy B: Involvement of calcium and arachidonate metabolism in acetylated-low-density-lipoprotein-stimulated tumor-necrosis-factor-alpha production by rat peritoneal macrophages. Eur J Biochem 253: 345-353, 1998.

6. Ji KT, Qian L, Nan JL, Xue YJ, Zhang SQ, Wang GQ, Yin RP, Zhu YJ, Wang LP, Ma J, et al: Ox-LDL induces dysfunction of endothelial progenitor cells via activation of NF- $\kappa \mathrm{B}$. Biomed Res Int 2015: 175291, 2015.

7. Fenyo IM and Gafencu AV: The involvement of the monocytes/macrophages in chronic inflammation associated with atherosclerosis. Immunobiology 218: 1376-1384, 2013.

8. Shinmura K: Cardiovascular protection afforded by caloric restriction: Essential role of nitric oxide synthase. Geriatr Gerontol Int 11: 143-156, 2011.

9. Tousoulis D, Kampoli AM, Tentolouris C, Papageorgiou N and Stefanadis C: The role of nitric oxide on endothelial function. Curr Vasc Pharmacol 10: 4-18, 2012.

10. Andrew PJ and Mayer B: Enzymatic function of nitric oxide synthases. Cardiovasc Res 43: 521-531, 1999.

11. Wyatt AW, Steinert JR and Mann GE: Modulation of the L-arginine/nitric oxide signalling pathway in vascular endothelial cells. Biochem Soc Symp 71: 143-156, 2004.

12. Xia Z and Vanhoutte PM: Nitric oxide and protection against cardiac ischemia. Curr Pharm Des 17: 1774-1782, 2011.

13. Godfraind T: Calcium channel blockers in cardiovascular pharmacotherapy. J Cardiovasc Pharmacol Ther 19: 501-515, 2014.
14. Pitt B, Byington RP, Furberg CD, Hunninghake DB, Mancini GB, Miller ME and Riley W: Effects of amlodipine on the progression of atherosclerosis and the occurrence of clinical events. PREVENT Investigators. Circulation 102: 1503-1510, 2000.

15. Komoda $\mathrm{H}$, Inoue $\mathrm{T}$ and Node $\mathrm{K}$ : Anti-inflammatory properties of azelnidipine, a dihydropyridine-based calcium channel blocker. Clin Exp Hypertens 32: 121-128, 2010.

16. Hassan MQ, Akhtar MS, Akhtar M, Ansari SH, Ali J, Haque SE and Najmi AK: Benidipine prevents oxidative stress, inflammatory changes and apoptosis related myofibril damage in isoproterenol-induced myocardial infarction in rats. Toxicol Mech Methods 25: 26-33, 2015.

17. Navadiya $K$ and Tiwari S: Pharmacology, efficacy and safety of felodipine with a focus on hypertension and angina pectoris. Curr Drug Saf 10: 194-201, 2015.

18. Yao R, Cheng X, Liao YH, Chen Y, Xie JJ, Yu X, Ding YJ and Tang TT: Molecular mechanisms of felodipine suppressing atherosclerosis in high-cholesterol-diet apolipoprotein E-knockout mice. J Cardiovasc Pharmacol 51: 188-195, 2008.

19. Tan HW, Xing SS, Bi XP, Li L, Gong HP, Zhong M, Zhang Y and Zhang W: Felodipine attenuates vascular inflammation in a fructose-induced rat model of metabolic syndrome via the inhibition of $\mathrm{NF}-\kappa \mathrm{B}$ activation. Acta Pharmacol Sin 29: 1051-1059, 2008

20. Jaffe EA, Nachman RL, Becker CG and Minick CR: Culture of human endothelial cells derived from umbilical veins. Identification by morphologic and immunologic criteria. J Clin Invest 52: 2745-2756, 1973.

21. Kannan Y, Sundaram K, Aluganti Narasimhulu C, Parthasarathy S and Wewers MD: Oxidatively modified low density lipoprotein (LDL) inhibits TLR2 and TLR4 cytokine responses in human monocytes but not in macrophages. J Biol Chem 287: 23479-23488, 2012.

22. Buege JA and Aust SD: Microsomal lipid peroxidation. Methods Enzymol 52: 302-310, 1978.

23. Khodarev NN, Yu J, Nodzenski E, Murley JS, Kataoka Y, Brown CK, Grdina DJ and Weichselbaum RR: Method of RNA purification from endothelial cells for DNA array experiments. Biotechniques 32: 316-320, 2002.

24. Livak KJ and Schmittgen TD: Analysis of relative gene expression data using real-time quantitative PCR and the 2(-Delta Delta C(T)) method. Methods 25: 402-408, 2001.

25. Green LC, Wagner DA, Glogowski J, Skipper PL, Wishnok JS and Tannenbaum SR: Analysis of nitrate, nitrite and $15 \mathrm{~N}$ nitrate in biological fluids. Anal Biochem 126: 131-138, 1982.

26. Zhang HP, Zheng FL, Zhao JH, Guo DX and Chen XL: Genistein inhibits ox-LDL-induced VCAM-1, ICAM-1 and MCP-1 expression of HUVECs through heme oxygenase-1. Arch Med Res 44: 13-20, 2013.

27. Kandola K, Bowman A and Birch-Machin MA: Oxidative stress-a key emerging impact factor in health, ageing, lifestyle and aesthetics. Int J Cosmet Sci 37 (Suppl 2): S1-S8, 2015.

28. Gimbrone MA Jr and García-Cardeña G: Endothelial cell dysfunction and the pathobiology of atherosclerosis. Circ Res 118: 620-636, 2016.

29. GB: Antiatherosclerotic effects of calcium channel blockers. Prog Cardiovasc Dis 45: 1-20, 2002.

30. Uetake Y and Shimosawa T: Antiatherosclerotic hopes of calcium channel blockers. Clin Calcium 15: 1689-1694, 2005 (In Japanese).

31. Simon A and Levenson J: Effects of calcium channel blockers on atherosclerosis: New insights. Acta Cardiol 57: 249-255, 2002.

32. Katouah H, Chen A, Othman I and Gieseg SP: Oxidised low density lipoprotein causes human macrophage cell death through oxidant generation and inhibition of key catabolic enzymes. Int $\mathrm{J}$ Biochem Cell Biol 67: 34-42, 2015.

33. Tang TH, Chang CT, Wang HJ, Erickson JD, Reichard RA, Martin AG, Shannon EK, Martin AL, Huang YW and Aronstam RS: Oxidative stress disruption of receptor-mediated calcium signaling mechanisms. J Biomed Sci 20: 48, 2013.

34. Limbu S, Hoang-Trong TM, Prosser BL, Lederer WJ and Jafri MS: Modeling local X-ROS and calcium signaling in the heart. Biophys J 109: 2037-2050, 2015.

35. Levine AB, Punihaole D and Levine TB: Characterization of the role of nitric oxide and its clinical applications. Cardiology 122: 55-68, 2012.

36. Sukhovershin RA, Yepuri G and Ghebremariam YT: Endothelium-derived nitric oxide as an antiatherogenic mechanism: Implications for therapy. Methodist Debakey Cardiovasc J 11: 166-171, 2015. 
37. Ponnuswamy P, Schröttle A, Ostermeier E, Grüner S, Huang PL, Ertl G, Hoffmann U, Nieswandt B and Kuhlencordt PJ: ENOS protects from atherosclerosis despite relevant superoxide production by the enzyme in apoE mice. PLoS One 7: e30193, 2012

38. Kuhlencordt PJ, Gyurko R, Han F, Scherrer-Crosbie M, Aretz TH, Hajjar R, Picard MH and Huang PL: Accelerated atherosclerosis, aortic aneurysm formation, and ischemic heart disease in apolipoprotein E/endothelial nitric oxide synthase double-knockout mice. Circulation 104: 448-454, 2001.

39. Ozaki M, Kawashima S, Yamashita T, Hirase T, Namiki M, Inoue N, Hirata K, Yasui H, Sakurai H, Yoshida Y, et al: Overexpression of endothelial nitric oxide synthase accelerates atherosclerotic lesion formation in apoE-deficient mice. J Clin Invest 110: 331-340, 2002.

40. Miyoshi T, Li Y, Shih DM, Wang X, Laubach VE, Matsumoto AH Helm GA, Lusis AJ and Shi W: Deficiency of inducible NO synthase reduces advanced but not early atherosclerosis in apolipoprotein E-deficient mice. Life Sci 79: 525-531, 2006.

41. Khan NA, Chattopadhyay P, Abid M, Pawdey A, Kishore K and Wahi AK: Protective effects of amlodipine on mitochondrial injury in ischemic reperfused rat heart. J Environ Biol 33: 591-595, 2012.

42. Sirmagül B, Ozdener F, Gulbas Z and Erol K: Calcium channel blockers increase the amount of nitrite production in rabbits without decreasing the responsiveness of platelets to collagen. Clin Exp Med 7: 142-148, 2007.

43. Matsubara M, Yao K and Hasegawa K: Benidipine, a dihydropyridine-calcium channel blocker, inhibits lysophosphatidylcholine-induced endothelial injury via stimulation of nitric oxide release. Pharmacol Res 53: 35-43, 2006.

44. Mason RP, Jacob RF, Corbalan JJ, Kaliszan R and Malinski T: Amlodipine increased endothelial nitric oxide and decreased nitroxidative stress disproportionately to blood pressure changes. Am J Hypertens 27: 482-488, 2014.

45. Sharma A, Trane A, Yu C, Jasmin JF and Bernatchez P: Amlodipine increases endothelial nitric oxide release by modulating binding of native eNOS protein complex to caveolin-1. Eur J Pharmacol 659: 206-212, 2011.

46. Hayashi T, Yamaguchi T, Sakakibara Y, Taguchi K, Maeda M, Kuzuya M and Hattori Y: ENOS-dependent antisenscence effect of a calcium channel blocker in human endothelial cells. PLoS One 9: e88391, 2014.
47. Zhang $\mathrm{X}$ and Hinze TH: Amlodipine release nitric oxide from canine coronary microvessels. An unexpected mechanism of action of a calcium channelblocking agent. Circulation 97: 576-580, 1998.

48. Yang J, Fukuo K, Morimoto S, Niinobu T, Suhara T and Ogihara T: Pranidipine enhances the action of nitric oxide released from endothelial cells. Hypertension 35: 82-85, 2000.

49. Yamamoto E, Nakamura T, Kataoka K, Tokutomi Y, Dong YF, Fukuda M, Nako H, Yasuda O, Ogawa H and Kim-Mitsuyama S: Nifedipine prevents vascular endothelial dysfunction in a mouse model of obesity and type 2 diabetes, by improving eNOS dysfunction and dephosphorylation. Biochem Biophys Res Commun 403: 258-263, 2010.

50. Rochette L, Lorin J, Zeller M, Guilland JC, Lorgis L, Cottin Y and Vergely C: Nitric oxide synthase inhibition and oxidative stress in cardiovascular diseases: Possible therapeutic targets? Pharmacol Ther 140: 239-257, 2013.

51. Gu JH, Ge JB, Li M, Wu F, Zhang W and Qin ZH: Inhibition of NF- $\kappa \mathrm{B}$ activation is associated with anti-inflammatory and anti-apoptotic effects of Ginkgolide B in a mouse model of cerebral ischemia/reperfusion injury. Eur J Pharm Sci 47: 652-660, 2012.

52. Garcia-Bonilla L, Moore JM, Racchumi G, Zhou P, Butler JM, Iadecola $\mathrm{C}$ and Anrather J: Inducible nitric oxide synthase in neutrophils and endothelium contributes to ischemic brain injury in mice. J Immunol 193: 2531-2537, 2014.

53. Gregersen I, Holm S, Dahl TB, Halvorsen B and Aukrust P: A focus on inflammation as a major risk factor for atherosclerotic cardiovascular diseases. Expert Rev Cardiovasc Ther 14: 391-403, 2016

54. Rosenfeld ME: Inflammation and atherosclerosis: Direct versus indirect mechanisms. Curr Opin Pharmacol 13: 154-160, 2013.

55. Gerhardt T and Ley K: Monocyte trafficking across the vessel wall. Cardiovasc Res 107: 321-330, 2015.

56. Yamashita T, Sasaki N, Kasahara K and Hirata K: Antiinflammatory and immune-modulatory therapies for preventing atherosclerotic cardiovascular disease. J Cardiol 66: 1-8, 2015. 